\title{
Restriction Endonuclease Cleavage Site and Length Polymorphisms in Mitochondrial DNA of Apis mellifera mellifera and $A$. m. carnica (Hymenoptera: Apidae)
}

\author{
DEBORAH ROAN SMITH' ${ }^{12}$ AND WESLEY M. BROWN 2 \\ Museum of Zoology, University of Michigan, \\ Ann Arbor, Michigan 48109
}

\begin{abstract}
Ann. Entomol. Soc. Am. 83(1): 81-88 (1990)
ABSTRACT Restriction endonuclease cleavage maps of mitochondrial DNAs of Scandinavian Apis mellifera mellifera L., of German, Austrian, and Yugoslavian A. m. carnica Pollman, and of Austrian "Nigra" honey bees are compared with previously published maps of mitochondrial DNA from North American bees of European ancestry and Brazilian Africanized bees. A. m. mellifera mitochondrial DNA is characterized by a pattern of cleavage sites unique among the honey bee populations thus far investigated. Variation in size of the mitochondrial DNA molecule is common among families (hives) of $A$. m. mellifera and appears to involve several distinct regions that span a region at least 5.1 kilobase pairs in length. Some elements of size variation seem to be confined to the A. m. mellifera population, whereas others are shared with Africanized bees. A. m. carnica mitochondrial DNA is characterized by a pattern of cleavage sites, which differs from that of $A$. $m$. mellifera and the Africanized bees but is similar to that of the domestic North American bees of European ancestry.
\end{abstract}

KEY WORDS Insecta, Apis mellifera, Africanized honey bee, mitochondrial DNA

Apis mellifera L. is subdivided into approximately 24 named geographic races or subspecies (Ruttner 1988). These subspecies are believed to be recent in origin; for example, the principal subspecies in Europe may have differentiated from one another during the Pleistocene glacial periods, when European honey bee populations were probably confined to refugia around the Mediterranean (Ruttner 1988).

* Apis mellifera subspecies are defined and identified largely by morphometric criteria (e.g., Alpatov 1929, Cornuet et al. 1975, Daly \& Balling 1978, Ruttner et al. 1978, Ruttner 1986), but they also differ in behavior, physiology, and ecology (Adam 1951, 1954, 1961, 1964, 1977; Ruttner 1988). Differences in allele frequencies have been found among subspecies at several polymorphic loci (e.g., Mestriner \& Contel 1972; Contel et al. 1977; Martins et al. 1977; Sylvester 1982; Del Lama et al. 1985, 1988; Spivak et al. 1988). These polymorphisms are useful in the study of honey bee biogeography and population biology (e.g., Cornuet 1979; Sheppard \& Berlocher 1984, 1985; Cornuet et al. 1986; Sheppard \& McPheron 1986) and in the study of Africanized bees (Nunamaker \& Wilson 1981, Sylvester 1982, Nunamaker et al. 1984).

Polymorphisms in mitochondrial DNA (mtDNA) complement and extend studies of allozyme

\footnotetext{
'Insect Division

${ }^{2}$ Laboratory for Molecular Systematics.
}

variation in a number of ways. Because animal mtDNA is typically maternally inherited without recombination (e.g., Dawid \& Blackler 1972, Reilly \& Thomas 1980; Lansman et al. 1983; Brown 1985), genetic markers on mtDNA can be used to determine the maternal ancestry of hybrid individuals and, thus, the directionality of gene flow in hybrid zones or hybrid populations (Wright et al. 1983, Avise \& Saunders 1984, Gyllensten et al. 1985). In addition, because animal mtDNA does not undergo recombination during sexual reproduction, it is passed intact along maternal lineages. This allows identification of the populations that have contributed to a hybrid population even after many generations of hybridization or backcrossing, or both (Ferris et al. 1982, Wright et al. 1983, Tegelström 1987).

Several practical considerations make the use of mtDNA particularly attractive in the study of honey bee population biology. First, although honey bees appear to have relatively low levels of allozyme variability (e.g., Sheppard \& Berlocher 1984 , $1985)$, the level of variation in their mtDNA is well within the range found in other species (Avise \& Lansman 1983). Second, although no fixed differences in allozymes have been found among honey bee subspecies, preliminary studies of the mtDNAs of European and African subspecies (Smith 1988; D.R.S., unpublished data) indicate that at least some have unique cleavage site patterns. Finally, because all the offspring of a queen inherit the same 
mtDNA, large quantities of mtDNA from a single source can be prepared by pooling tissue from hive mates.

The Carniolan honey bee, Apis mellifera carnica Pollmann, is native to Yugoslavia, Austria south of the Alps, and parts of Hungary, Rumania, and Bulgaria (Ruttner 1975, 1988). Because of its gentle disposition, good overwintering abilities, and good honey production, this subspecies is popular among commercial and amateur beekeepers and has been imported to other parts of Europe and to the New World. It is now one of the most widely distributed of the honey bee subspecies (Ruttner 1975). Apis mellifera mellifera $\mathrm{L}$. originally occupied Britain nd north and central Europe (Ruttner 1988). Toay its range, at least in domesticated populations, as been dramatically altered by human prefernces. A. m. ligustica Spinola and A. $m$. carnica lave been introduced into many parts of $A . m$. mellifera's range, and in some domestic populations (e.g., Germany, Switzerland) they have largely replaced native A. m. mellifera (Ruttner 1975). Thus care was exercized in the selection of the $A$. $m$. mellifera populations we sampled. The Swiss and Austrian "Nigra" honey bees are hybrids of A. m. mellifera, originally native to these areas, and imported A. m. carnica.

Our study presents cleavage site maps and an analysis of length variation in $A . m$. mellifera, $A$. m. carnica, and "Nigra" mtDNA as well as comparisons between these mtDNAs and those of North American bees of European ancestry and Brazilian Africanized bees. This is part of a continuing survey of mtDNA in A. mellifera subspecies.

\section{Materials and Methods}

Collections. Fifty to 200 adult worker bees were collected from each hive. Heads and thoraces were frozen in liquid nitrogen and transported to the laboratory, where they were stored at $-80^{\circ} \mathrm{C}$ until they were used in the preparation of mtDNA.

Samples of $A . m$. carnica were collected from Graz, Villach, and the Institut für Bienenkunde, Lunz-am-See, Austria. The research aplary at Lunzam-See maintains imported colonies as well as local honey bees. Samples collected at the Institut für Bienenkunde included hives from Medvode (Slovenia) and Split (Dalmatia), Yugoslavia; Hamburg, West Germany; and Vienna and Lunz-am-See, Austria. Graz, Villach, Vienna, Medvode, and Split lie within the original range of $A . m$. carnica. Lunzam-See lies outside the original range of $A . m$. carnica, but $A$. m. carnica is well established in the area now and most domestic hives are this subspecies (Ruttner 1988). The Hamburg sample is an example of the A. $m$. carnica that have been imported extensively into northern and western $\mathrm{Eu}$ rope and that have largely replaced domesticated A. $m$. mellifera over much of that subspecies' original range.
Because A. m. mellifera has been replaced of hybridized with other subspecies throughout muct of its range, bees for this study were collected from apiaries whose hives were known to consist maink of $A . m$. mellifera and for which the history of importation and breeding was relatively well known. Samples of A. m. mellifera were collected from Laesø, Denmark (the island of Laesø is now a preserve for A. m. mellifera, and importation of other subspecies is forbidden; S. Toft, personal communication); Billingstad, near Asker, Norway and Uppsala, Sweden. Samples of the honey bee strain "Nigra" were collected from Otztalbanhof Austria. Subspecies identifications have been corroborated by morphological measurements and al. lozyme analysis (D.R.S. \& B. Crespi, unpublished data).

MtDNA was prepared from three hives each from Graz (Grazl-3), Villach (Villl-3), and Split (Dalm l-3); two hives each from Vienna (Wienl2) and Medvode (Slovl-2); one hive each from Lunz-am-See (LunzI) and Hamburg (Hambl) seven hives from Laesø (Laesøl-7); three hives each from Asker (Asker 1-3) and Uppsala (Upps l-3); and from nine hives from Ötztalbanhof (Nigral-9).

Preparation and Analysis of mtDNA. Mitochondrial DNA was prepared from frozen thoraces of about 25 adult worker bees from each hive by the method described by Wright et al. (1983) with the following modifications of the tissue homogenization procedure. Batches of 15-25 thoraces were ground to a powder in liquid nitrogen with a ramic mortar and pestle. The powdered tissue (mostly flight muscle) was resuspended either in 10 $\mathrm{ml}$ of $10 \mathrm{mM} \mathrm{NaCl}, 10 \mathrm{mM}$ Tris, $200 \mathrm{mM}$ EDTA, $\mathrm{pH} 7.5$, or in $10 \mathrm{ml}$ of $10 \mathrm{mM}$ Tris, $10 \mathrm{mM}$ EDTA (TE), pH 7.5. $1.2 \mathrm{ml}$ of $20 \%$ sodium dodecyl sulfate (SDS) was added, and the mixture was incubated for 10-20 min at room temperature to lyse cell and organelle membranes. $3.5 \mathrm{ml}$ of $\mathrm{CsCl}$-saturated TE was then added, and the mixture was incubated on ice for 15-30 min to precipitate SDS and proteins. The mixture was centrifuged at $17,000 \times$ $\left(12,000 \mathrm{rpm}\right.$ in a Beckman JA-17 rotor) at $4^{\circ} \mathrm{C}$ for $10 \mathrm{~min}$ to pellet cellular debris; $1-2 \mathrm{ml}$ of propidium iodide $(2 \mathrm{mg} / \mathrm{ml}$ in $\mathrm{TE}$ ) was added to the supernatant, and the density of the solution was adjusted to $1.56-1.57 \mathrm{~g} / \mathrm{ml}$ with solid $\mathrm{CsCl}$. $\mathrm{CsCl}$ density centrifugation and sample recovery fol. lowed the methods described in Wright et al. (1983)

Aliquots of each mtDNA sample were digested with each of 15 restriction enzymes (AccI, Aval, BclI, BglII, EcoOl09, EcoRI, EcoRV, Hincll, HindIII, NdeI, PstI, PvuII, SpeI, XbaI, and Xhol, using the buffer conditions recommended by the suppliers (Bethesda Research Laboratories, Gaith ersburg, Md.; International Biotechnologies, New Haven, Conn.; New England BioLabs, Beverly, Mass.; Boehringer Mannheim Biochemicals, Indianapolis). Each of these enzymes recognizes and cleaves a particular sequence or sequences of six basepairs. The resulting DNA fragments were ra. 
Table 1. Percentage sequence divergence among the mitochondrial genomes of $A$. m. carnica, A. m. mellifera, a North American hive of European ancestry (USA 1), and a Brazilian Africanized hive (Brzl)

\begin{tabular}{lccccccccc}
\hline & Carl & Car2 & Car3 & USA1 & Brzl & Mell & Mel2 & Mel3 & Mel4 \\
\hline Carl & - & 0.0097 & 0.0033 & 0.0033 & 0.0269 & 0.0372 & 0.0340 & 0.0291 & 0.0324 \\
Car2 & 0.0057 & - & 0.0063 & 0.0063 & 0.0291 & 0.0388 & 0.0356 & 0.0310 & 0.0341 \\
Car3 & 0.0033 & 0.0045 & - & 0.0065 & 0.0304 & 0.0405 & 0.0372 & 0.0324 & 0.0356 \\
USA1 & 0.0033 & 0.0045 & 0.0047 & - & 0.0223 & 0.0324 & 0.0291 & 0.0246 & 0.0278 \\
Brz1 & 0.0109 & 0.0111 & 0.0116 & 0.0096 & - & 0.0269 & 0.0233 & 0.0269 & 0.0223 \\
Mel1 & 0.0129 & 0.0129 & 0.0135 & 0.0117 & 0.0109 & - & 0.0034 & 0.0068 & 0.0033 \\
Mel2 & 0.0123 & 0.0123 & 0.0129 & 0.0111 & 0.0101 & 0.0035 & - & 0.0105 & 0.0068 \\
Mel3 & 0.0111 & 0.0112 & 0.0117 & 0.0099 & 0.0109 & 0.0049 & 0.0063 & - & 0.0033 \\
Mel4 & 0.0117 & 0.0117 & 0.0123 & 0.0106 & 0.0096 & 0.0033 & 0.0049 & 0.0033 & - \\
\hline
\end{tabular}

The method of Nei \& Tajima (1983) was used to estimate the mean number of nucleotide substitutions per site (above the diagonal) and standard deviation of the mean (below the diagonal) using comparisons of the mapped cleavage sites produced by nondegenerate six base pair restriction enzymes (BclI, BglII, EcoO109, EcoRI, EcoRV, HindIII, NdeI, PstI, PvulI, SpeI, XbaI, and Xhol). A. m. mellifera restriction morphs (Mell-Mel4) as in Fig. 2, A. m. carnica restriction morphs (Car1-Car3) as in Fig. 3

dioactively end-labeled with ${ }^{32} \mathrm{P}$-deoxynucleotides using the large (Klenow) fragment of DNA polymerase I and separated by electrophoresis on $1 \%$ agarose and $4 \%$ polyacrylamide gels (Brown 1980 , Ferris et al. 1981, Wright et al. 1983). The fragments were visualized by autoradiography. The lengths (in thousands of base pairs, or kilobase pairs, $\mathrm{kb}$ ) of the fragments were estimated by comparison of their mobilities with those of known-size standards run on each gel (Brown 1980, Wright et al. 1983). A map of the six base pair (bp) cleavage sites was constructed for each mtDNA by means of double digestions (Brown \& Vinograd 1974) and by comparison with previously constructed maps from North American honey bees of presumed European ancestry (probably A. m. ligustica or A. m. carnica) and Brazilian Africanized bees, presumed to be descendants of introduced $A . m$. scutellata (Smith \& Brown 1988). BglII restriction sites in the mtDNA of French A. m. mellifera and Italian A. $m$. ligustica were first mapped by J.-M. Cornuet (personal communication). Their location was confirmed in this study. Percentages of mtDNA sequence divergences among $A$. $m$. mellifera, $A . m$. carnica, an American hive of European ancestry, and a Brazilian Africanized hive were estimated by the method of Nei \& Tajima (1983) using only nondegenerate six base pair restriction enzyme cleavage sites (Table 1 ).

\section{Results and Discussion}

Both cleavage site and length polymorphisms occur in honey bee mtDNA. Fig. 1 shows examples of restriction-site polymorphisms among the mtDNAs of A. m. carnica, A. m. mellifera, and a hive of Brazilian Africanized bees. Two distinct restriction enzyme cleavage maps were found in this study, one typical of A. m. mellifera (Fig. 2) and a second typical of A. m. carnica (Fig. 3). Seven of the nine "Nigra" samples had $A . m$. mellifera mtDNA and two, Nigra 3 and 7 , had A. m. carnica mtDNA.

The mtDNAs of A. m. mellifera and A. m. carnica show very little intrapopulation variation in cleavage sites. Only the presence of two Spel sites and one Bcll site varied among Scandinavian $A$. m. mellifera and mellifera-like "Nigra" hives (Fig. 2). A. m. carnica and carnica-like "Nigra" hives differed in the presence or absence of two XbaI sites and one Ndel site (Fig. 3). The similarity of mtDNA cleavage maps within each subspecies is reflected in the low estimate of sequence divergence among the $A, m$. mellifera miDNAs (0.33-

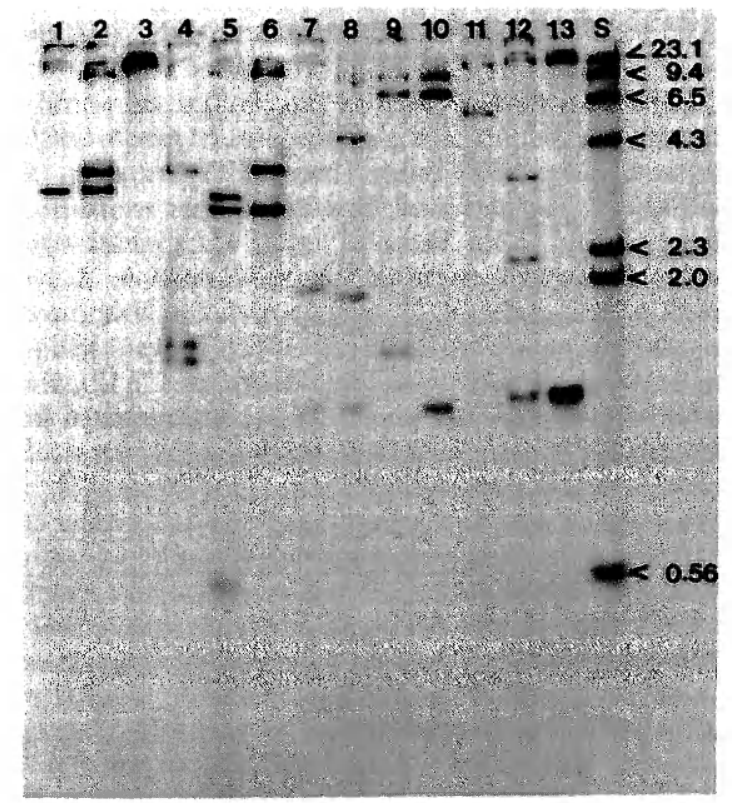

Fig. 1. Autoradiograph of $1 \%$ agarose gel showing restriction fragment length polymorphisms in mtDNA of A. m. carnica (lanes $1,4,7,8$, and 11), A. m. mellifera (lanes 2, 5, 9, and 12), and a Brazilian Africanized honey bee (lanes $3,6,10$, and 13). Samples were digested with the restriction endonucleases BglII (lanes 1-3), EcoRI (lanes 4-6), XbaI (lanes 7-10), and a double digest with EcoO109 and Spel (lanes 11-13; the band at approximately $3.3 \mathrm{~kb}$ in lane 11 is the result of partial digestion at the $0.5 \mathrm{~kb}$ Spel site). The size standard (lane S) is a HindIII digest of wild-type lambda phage DNA; size of fragments is given in kilobase pairs. 


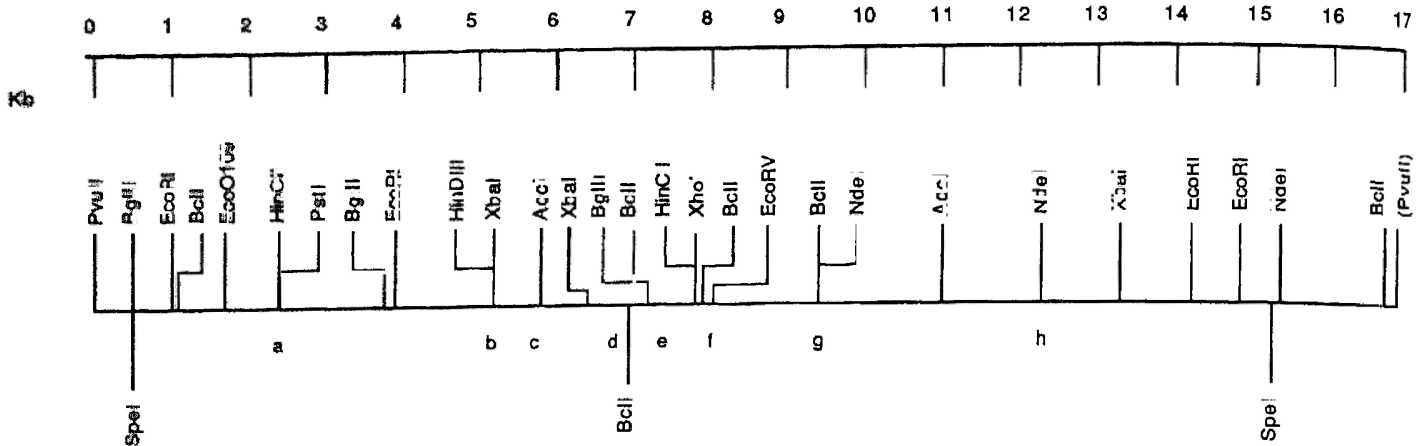

Fig. 2. Restriction enzyme cleavage site map of mtDNAs of Scandinavian A. m. mellifera and mellifera-like Austrian "Nigra" bees. The cleavage site for PvuII was arbitrarily chosen as the starting point for the map. Cleavage sites above the horizontal were common to all $A . m$. mellifera and mellifera-like "Nigra" mapped. The presence of sites below the horizontal (SpeI at $0.5 \mathrm{~kb}$, SpeI at $15.16 \mathrm{~kb}$, and BclI at $6.89 \mathrm{~kb}$ ) varied among restriction morphs Mell-Mel4) as follows: Mell, both SpeI sites present, BclI site absent, Laesøl-3, Askerl and 3, Nigra6 and 8; Mel2,

eI at 0.05 present, BclI and SpeI at 15.16 absent, Uppsl and 2; Mel3, SpeI at 15.16 and BclI present, SpeI at 0.05 ent, Upps3. Mel4, all 3 sites present, Laesø4-7, Asker2, Nigra2,4,5,9. Restriction-site mapping indicated that the rII and PstI sites at $2.4 \mathrm{~kb}$ were approximately $10 \mathrm{bp}$ apart, the Hincll site occurring before the PstI site sequent sequencing of this region by Vlasak et al. (1987) shows these sites to be $9 \mathrm{bp}$ apart; the region sequenced $0-3.0 \mathrm{~kb}$ on our map) encompasses most of the large subunit ribosomal DNA (Vlasak et al. 1987). The NdeI and II sites at approximately $9.4 \mathrm{~kb}$ were indistinguishable by restriction-site mapping. Subsequent sequencing of this sgion (Crozier et al. 1989) shows that these two restriction sites are overlapping. The HindIII and Xbal sites at $5.2 \mathrm{~kb}$ are approximately $50 \mathrm{bp}$ apart, the HindIII site occurring before the XbaI site. The HincII and XhoI sites at approximately $7.8 \mathrm{~kb}$ are approximately $15 \mathrm{bp}$ apart; their relative positions have not been determined. The letters below the horizontal refer to regions of size variation presented in Table 2 .

$1.00 \%)$ and among the A. m. carnica mtDNAs (0.33$0.97 \%$; Table 1).

However, the restriction site maps show substantial variation among subspecies. A. m. mellifera mtDNAs differ from those of $A . m$. carnica and the American and Brazilian bees examined (Fig. 4), and from those of other subspecies currently under investigation (A. m. ligustica, $A, m$. scutellata Lepeletier, A. m. capensis Escholtz, and A. $m$. therica Goetze; Smith [1988] and unpublished data). In particular, the HincII site at $7.7 \mathrm{~kb}$, the EcokI site at $14.7 \mathrm{~kb}$, and the Spel site at $16.16 \mathrm{~kb}$ (Fig. 2) have been found so far only in A. m. mel- lifera samples. Likewise, the absence of the HindIII site at approximately $6.3 \mathrm{~kb}$ and the Accl site at $11.03 \mathrm{~kb}$ appear to be characteristic of A. m. mellifera. The mtDNAs of A. m. carnica are not substantially different from that of USAl, a domestic North American hive $(0.33-0.47 \%$ sequence divergence; Table 1). This is not surprising, because domestic North American bees are primarily descendants of $A$. m. ligustica and A. m. carnica, and these two subspecies are themselves thought to be very closely related (Ruttner 1988). The differences between the cleavage maps of $A$. m. mellifera, $A$. m. carnica, USA1, and a Brazilian Africanized hive
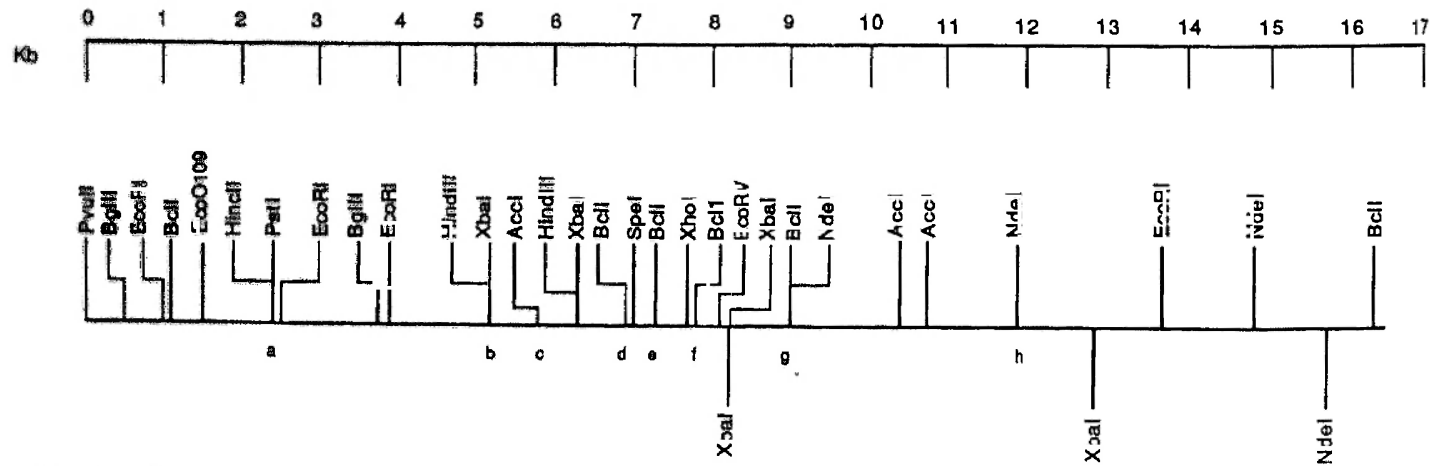

Fig. 3. Restriction enzyme cleavage site map of mtDNAs of $A$. m. carnica. Cleavage sites above the horizontal ere common to all $A . m$. carnica mapped. The presence of the sites below the horizontal (XbaI at 8.23 and 12.89 , Ndel 15.74) varied among restriction morphs (Carl-Car3) as follows: Carl, both XbaI sites and NdeI site absent, Grazl and 3, Slov1; Car2, both XbaI sites and NdeI site present, Vill3, Dalml and 3; Car3, both Xbal sites absent, Ndel site preserit, Hambl, Wienl and 2, Lunzl, Vill 1 and 2, Graz2, Dalm2, and Slov2. The letters below the horizontal refer to regions of size variation discussed in Table 2. 
A. m. carnica

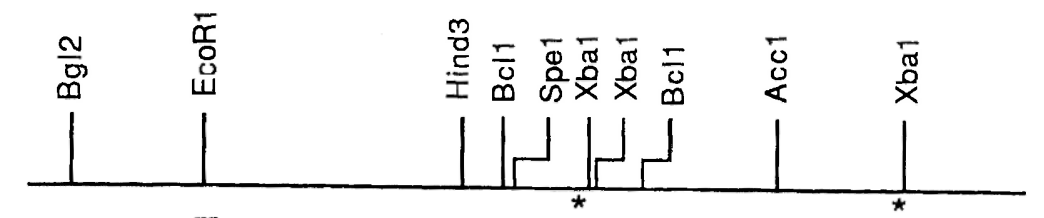

USA1

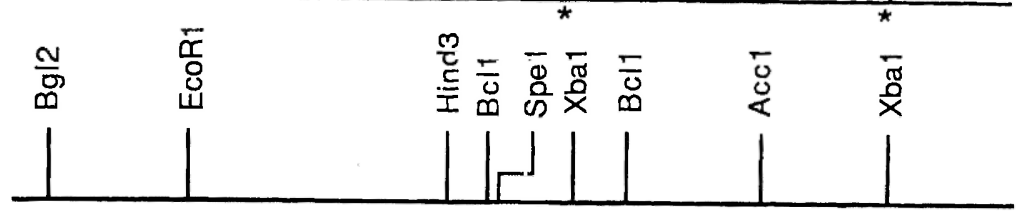

A. m. mellifera

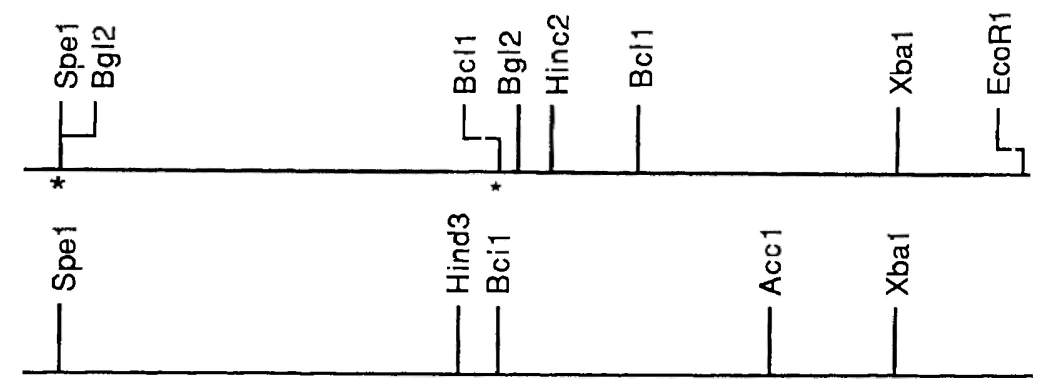

BRZ1

Fig. 4. Comparison of restriction enzyme cleavage site maps of A. m. mellifera, A. m. carnica, a Nor hive of European ancestry (USAl), and a Brazilian Africanized hive (BRZ1). The cleavage sites commo omitted. Asterisks indicate sites variable within populations.

$(B R Z 1)$ are reflected in their higher estimated sequence divergences (2.23-4.05\%; Table 1).

There is substantial variation among families (hives) in the size of the mtDNA molecule as well as size variation in mtDNA among subspecies ( $\mathrm{Ta}$ ble 2). Two regions of size variation are of particular interest. The region between the Xbal site at $5.23 \mathrm{~kb}$ (Fig. 2, b) and the Accl site at approximately $5.8 \mathrm{~kb}$ (Fig. 2, c) is longer in A. m. mellifera and the mellifera-like "Nigra" than the corresponding region in the American and Brazilian mtDNAs; it also is variable among $A . m$. mellifera families (Fig. 5). This variation is most easily explained by postulating a sequence $80-100 \mathrm{bp}$ in length which is present once (in Laesøl-7, Asker 13 , and Upps3), twice (in Upps1-2), or three times (Nigral-2,4-6,8-9) in A. m. mellifera and mellifera-like "Nigra" mtDNA, and which is absent from the mtDNAs of A. m. carnica and the North American and Brazilian bees sampled.
The region of $A . m$. mellifera mtDN the Bcll sites at $7.9 \mathrm{~kb}$ (Fig. 2 and 3 , $\mathrm{kb}$ (Fig. 2 and $3, \mathrm{~g}$ ) is $270 \mathrm{bp}$ large corresponding region in the mtDNA o this respect $A$. m. mellifera and the 1 Brazilian mtDNAs are similar. The cor region in the mtDNA of hive Upps3 mately $540 \mathrm{bp}$ larger than in USA1; 1 explained by assuming that the 270-bl is present twice in the mtDNA of Upp

The region between the Ndel sites (Fig. 2, g) and $12.26 \mathrm{~kb}$ (Fig. 2, h) is app $80 \mathrm{bp}$ larger in $A . m$. mellifera and th Africanized hive than in A. m. carnica

Size variation in mtDNA has been rep. in individuals, among conspecific indiv: among closely related species (e.g., Faur stenholme 1976, 1980a,b; Densmore e Harrison et al. 1985; Moritz \& Brown 1 Solignac et al. 1986; Moritz et al. 1987)

Table 2. Comparison of size variation in kilobase pairs (kb) in the mitochondrial genomes of $A$. $m$. ca mellifera, and a Brazilian Africanized bee (Brzl)

\begin{tabular}{lll}
\hline Location of fragment & A. m. carnica & \multicolumn{1}{c}{ A. m. mellifera } \\
\hline 1. PstI "a" to Xbal "b" & 2.78 & $2.8-2.87$ \\
2. Xbal "b" to Accl "c" & 0.53 & 0.62 in Laesøl-7, Asker1-3, Upps3 \\
& & 0.70 in Uppsl and 2 \\
& & 0.79 in Nigra 1-2, 4-6, 8-9 \\
3. Bcll "d" to Bcll "e" & 0.43 & Site "d" absent \\
4. Bcll "e" to Bcll "f" & 0.54 & 0.54 \\
5. Bcll "f" to BclI "g" & 1.19 & 1.73 in Upps3, 1.46 in all others \\
6. Ndel "g" to Ndel " $h$ " & 2.87 & 2.95 \\
& USA1 & \\
\hline
\end{tabular}

A. $m$ carnica fragment sizes are like those of a North American honey bee of European ancestry (USAl) except wher lowercase letters in quotes refer to restriction sites in Fig. 2 and 3. 


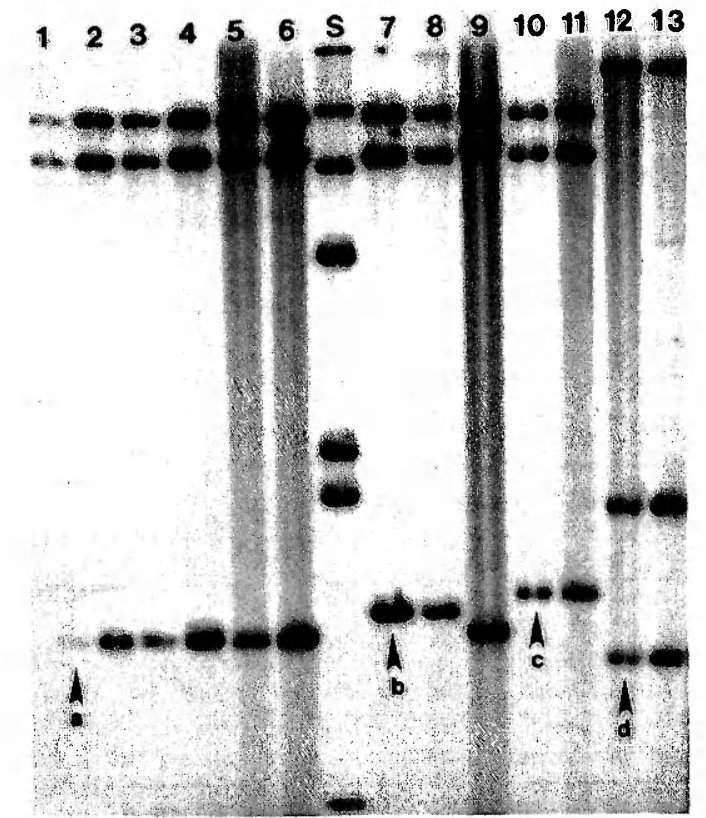

Fig. 5. Autoradiograph of $1 \%$ agarose gel showing A. $m$. mellifera and "Nigra" mtDNA digested with the enzyme Xbal. Lane 1, Laesø1; 2, Laesø2; 3, Laesø3; 4, Asker1; 5, Asker2; 6, Asker3; 7, Upps1; 8, Upps2; 9, Upps3; 10, Nigral; 11, Nigra2; 12, A. m. carnica (Grazl). Size standard is HindIII-digested lambda phage DNA. Note size variation in smallest Xbal fragment.

in Brown 1983, 1985). In many cases, this variation is located in or adjacent to the noncoding control region. However, the regions to which size variation in A. mellifera mtDNA have been mapped span a minimum of $5.1 \mathrm{~kb}$, or approximately onethird of the 16.8-kb genome, making it unlikely that all of these regions of size variation are in or adjacent to the control region.

In addition, Crozier et al. (1989) have sequenced a part of an A. m. ligustica mtDNA corresponding to the region from 6.5 to $9.5 \mathrm{~kb}$ on our maps. This region was found to include (reading from 6.5 to $9.5 \mathrm{~kb}$ ) aspartate tRNA, cytochrome oxidase I, leucine tRNA, a small unidentified reading frame, cytochrome oxidase II, and lycine and tryptophan tRNAs. The position of the (as yet) unidentified reading frame corresponds to one of the regions of size variation, namely the site which is $270 \mathrm{bp}$ larger in A. m. mellifera and Brazilian Africanized bees. This element of size variation clearly does not lie in the AT-rich control region.

Maternally inherited mtDNA polymorphisms can be used in conjunction with biparentally inherited characters such as allozyme or morphological phenotypes to detect the direction of gene flow in hybrid populations. This has practical application in the study of honey bee populations in the New World. For example, A. m. mellifera was the subspecies imported to North America by European colonists in the 17th century and was probably the most commonly imported bee until the middle of the 19th century (Oertel 1976, Pellet 1938). Today A. m. mellifera has been largely replaced in North American apiaries by other subspecies, particularly A. m. ligustica, A. m. carnica, and their hybrids. It is possible that the descendants of the early $A$. $m$. mellifera imports are present in North Amer. ican feral populations, as has been suggested by Sheppard (1988) on the basis of allozyme studies If so, matrilineal descendants of the early $A . m$. mellifera colonists should be identifiable by their characteristic mtDNA.

mtDNA polymorphisms also are useful in analyzing the pattern of gene flow between European and Africanized bees in the New World. Earlier work has shown differences in mtDNA cleavage patterns between North American bees of European ancestry and some Brazilian Africanized bees (Smith \& Brown 1988) and between European and African subspecies (Smith 1988). One critical ques. tion for the management of Africanized bees is the extent to which gene flow takes place from managed European apiary populations into feral Africanized populations. If swarms headed by European queens or hybrid queens (from European queen-African drone matings) routinely enter and survive in the feral population, the feral popula. tions should gradually acquire more European characteristics. On the other hand, if swarms head. ed by European queens or European-African hybrid queens are selected against in feral populations, the Africanized population advancing north might show relatively little European influence. The success of queens of European maternal ancestry in feral Africanized populations can be assessed by the relative frequencies of European and Africanized mtDNAs in these populations.

\section{Acknowledgment}

These collections could not have been made without the advice of $F$. Ruttner, who suggested populations to sample and provided information on the history of $A$. m. mellifera, A. m. carnica, and "Nigra" populations. We also thank N. and G. Koeniger (Institut für Bienenkunde, Oberursel, Federal Republic of Germany), $\mathrm{H}$ Pechhacker (Institut für Bienenkunde, Lunz-am-See, Austria), S. Toft (University of Aarhus, Aarhus, Denmark), H. Hansen (Statens Bisygdomsnieven, Lyngby, Denmark), A Hagen and A. Aarhus (Institut for Hus. dyrfag, Seksjon Biavl, Norges Landbrukshogskole, Asker, Norway), I. Fries (Swedish University of Agricultural Sciences, Department of Animal Husbandry, Bee Divi. sion, Uppsala, Sweden), and P. Pamilo (Department of Genetics, University of Helsinki, Finland). The bees sampled are from the apiaries of B. Stoklund, Laesø, Denmark; T. Gjessing, Billingstad, Norway; the Swedish University of Agricultural Sciences, Uppsala, Sweden; $P$ Lettenbichler, Ötztalbanhof, Austria; the Steirmark Imkerschule, Graz, Austria; J. Humele, Villach, Austria; and $\mathrm{H}$. Pechhacker, Institüt für Bienenkunde, Lunz-amSee, Austria. L. Vawter and R. Hagen made criticial comments on the manuscript. This work was supported by National Science Foundation (NSF) Grant SR-8709661 to D.R.S. and by NSF and National Institutes of Health grants to W.M.B. 


\section{References Cited}

Adam, Brother. 1951. In search of the best strains of bees. Bee World 32: 49-52.

1954. In search of the best strains of bee: second journey. Bee World 35: 193-203, 233-244.

1961. The honey bees of the Iberian peninsula. Bee World 42: 252-255.

1964. In search of the best strains of bee: concluding journeys. Bee World 45: 70-83, 104-118.

1977. In search of the best strains of bees: supplementary journey to Asia Minor, 1973. Bee World 58: $57-66$.

Alpatov, V. V. 1929. Biometrical studies on variation and the races of bees. Q. Rev. Biol. 4: 1-58.

Avise, J. C. \& R. A. Lansman. 1983. Polymorphisms of mitochondrial DNA in populations of animals, pp. 147-164. In M. Nei and R. K. Koehn [eds.], Evolution of genes and proteins. Sinauer, Sunderland, Mass.

Avise, J. C. \& N. C. Saunders. 1984. Hybridization and introgression among species of sunfish (Lepomis): analysis by mitochondrial DNA and allozyme markers. Genetics 108: 237-255.

Brown, W. M. 1980. Polymorphisms in mitochondrial DNA of humans as revealed by restriction endonuclease analysis. Proc. Natl. Acad. Sci. U.S.A. 77: 36053609.

1983. Evolution of animal mitochondrial DNA, pp. 62-88. In M. Nei \& R. K. Koehn [eds.], Evolution of genes and proteins. Sinauer, Sunderland, Mass.

1985. The mitochondrial genome of animals, pp. 95130. In R. J. MacIntyre [ed.], Molecular evolutionary genetics. Plenum, New York.

Brown, W. M. \& J. Vinograd. 1974. Restriction endonuclease cleavage maps of animal mitochondrial DNA. Proc. Natl. Acad. Sci. U.S.A. 71: 4617-4621.

Contel, E. P. B., M. A. Mestriner \& E. Martins. 1977. Genetic control and developmental expression of malate dehydrogenase in Apis mellifera. Biochem. Genet. 15: 859-876.

Cornuet, J.-M. 1979. The MDH system in honeybees of Guadaloupe. J. Hered. 70: 223-224.

Cornuet, J.-M., J. Fresnaye \& L. Tassencourt. 1975. Discrimination et classification de populations d'abeilles à partir de charactères biometrique. Apidologie 6: 145-187.

Cornuet, J.-M., A. Daoudi \& C. Chevalet. 1986. Genetic pollution and number of matings in a black honey bee (Apis mellifera mellifera) population. Theor. Appl. Genet. 73: 223-227.

Crozier, R. H., Y. C. Crozier \& A. G. MacKinlay. 1989. The CO-I and CO-II region of honey-bee mitochondrial DNA: evidence for variation in insect mitochondrial evolutionary rates. Molec. Biol. Evol. 6: 399-411.

Daly, H. \& S. V. Balling. 1978. Identification of Africanized honeybees in the western hemisphere by discriminant analysis. J. Kans. Entomol. Soc. 51: 957969.

Dawid, I. B. \& A. W. Blackler. 1972. Maternal and cytoplasmic inheritance of mitochondrial DNA in Xenopus. Dev. Biol. 29: 152-161.

Del Lama, M. A., M. A. Mestriner \& J. C. A. Paiva. 1985. Est-5 and PGM1, new polymorphisms in Apis mellifera. Rev. Rras. Genet. 8: 17-27.

Del Lama, M. A., R. A. Figueiredo, A. E. E. Soares \& S. N. Del Lama. 1988. Hexokinase polymorphism in Apis mellifera and its use for Africanized honeybee identification. Rev. Bras. Genet. 11: 287-297.
Densmore, L. D., J. W. Wright \& W. M. Brown. 1985. Length variation and heteroplasmy are frequent in mitochondrial DNA from parthenogenetic and bisexual lizards (genus Cnemidophorus). Genetics 110: 689-707.

Fauron, C. M.-R. \& D. R. Wolstenholme. 1976. Structural heterogeneity of mitochondrial DNA molecules within the genus Drosophila. Proc. Natl. Acad. Sci. U.S.A. 73: 3623-3627.

1980a. Extensive diversity among Drosophila species with respect to nucleotide sequences within the adenine + thymine-rich region of mitochondrial DNA molecules. Nucleic Acids Res. 8: 2439-2452.

$1980 \mathrm{~b}$. Intraspecific diversity of nucleotide sequences within the adenine + thymine-rich region of mitochondrial DNA molecules of Drosophila mauritiana, Drosophila melanogaster and Drosophila simulans. Nucleic Acids Res. 8: 5391-5410.

Ferris, S. D., A. C. Wilson \& W. M. Brown. 1981. Evolutionary tree for apes and humans based on cleavage maps of mitochondrial DNA. Proc. Natl. Acad. Sci. U.S.A. 78: 2432-2436.

Ferris, S. D., R. D. Sage \& A. C. Wilson. 1982. Evidence from mtDNA sequences that common laboratory strains of mice are descended from a single female. Nature (London) 295: 163-165.

Gyllensten, U., R. F. Leary, F. W. Allendorf \& A. C. Wilson. 1985. Introgression between two cutthroat trout subspecies with substantial karyotypic, nuclear and mitochondrial genomic divergence. Genetics 109: 905-915.

Harrison, R. G., D. M. Rand \& W. C. Wheeler. 1985. Mitochondrial DNA size variation within individual crickets. Science 228: 1446-1448.

Lansman, R. A., J. C. Avise \& M. Heuttel. 1983. Critical experimental test of the possibility of "paternal leakage" of mitochondrial DNA. Proc. Natl. Acad. Sci. U.S.A. 80: 1969-1971.

Martins, E., M. A. Mestriner \& E. P. B. Contel. 1977. Alcohol dehydrogenase polymorphisms in Apis mellifera. Biochem. Genet. 15: 357-366.

Mestriner, M. A. \& E. P. B. Contel. 1972. The P-3 and Est loci in the honey bee Apis mellifera. Genetics 72: 733-738.

Moritz, C. \& W. M. Brown. 1986. Tandem duplication of D-loop and ribosomal RNA sequences in lizard mitochondrial DNA. Science 233: 1425-1427.

1987. Tandem duplications in animal mitochondrial DNAs: variation in incidence and gene content among lizards. Proc. Natl. Acad. Sci. U.S.A. 84; 7183-7187.

Moritz, C., T. E. Dowling \& W. M. Brown. 1987. Evolution of animal mitochondrial DNA: relevance for population for population biology and systematics. Annu. Rev. Ecol. Svst. 18: 269-292.

Nei, M. \& F. Tajima. 1983. Maximum likelihood estimation of the number of nucleotide substitutions from restriction sites data. Genetics 105: 207-217.

Nunamaker, R. A. \& W. T. Wilson. 1981. Comparison of $M d h$ allozyme patterns in the African honey bee (Apis mellifera adansonii) and the Africanized populations of Brazil. J. Kans. Entomol. Soc. 54: 704710.

Nunamaker, R. A., W. T. Wilson \& B. E. Haley. 1984. Electrophoretic detection of Africanized honeybees (Apis mellifera scutellata) in Guatemala and Mexico based on malate dehydrogenase allozyme patterns. J. Kans. Entomol. Soc. 57: 622-631.

Oertel, E. 1976. Early records of honey bees in the 
eastern United States. Am. Bee J. 116: 70-71, 114, 128, 156-157, 214-215, 260-261, 290.

Pellet, F. C. 1938. History of American bee-keeping. Collegiate, Ames, Iowa.

Reilley, J. G. \& C. A. Thomas, Jr. 1980. Length polymorphisms, restriction site variation and maternal inheritance of mitochondrial DNA of Drosophila melanogaster. Plasmid 3: 109-115.

Ruttner, F. 1975. The races of honey bees, pp. 20 38. In The hive and the honey bee. Dadant, Carthage, Ill.

1986. Geographical variability and classification, $\mathrm{pp}$ 23-56. In T. Rinderer [ed.], Bee genetics and breeding. Academic, New York

1988. Biogeography and taxonomy of honeybees. Springer, New York.

Ruttner, F., L. Tassencourt \& J. Louveaux. 1978. Biometrical-statistical analysis of the geographic variability of $A$. mellifera $\mathrm{L}$. Apidologie 9: 363-381.

Sheppard, W.S. 1988. Comparative study of enzyme polymorphism in United States and European honey bee (Hymenoptera: Apidae) populations. Ann. Entomol. Soc. Am, 81: 886-889.

Sheppard, W. S. \& S. H. Berlocher. 1984. Enzyme polymorphism in Apis mellifera from Norway. J. Apic Res. 23: 64-69.

1985. New allozyme variability in Italian honey bees. J. Hered. 76: 45-48.

Sheppard, W. S. \& B. A. McPheron. 1986. Genetic variation in honey bees from an area of racial hybridization in western Czechoslovakia. Apidologie 17: 21-32.

Smith, D. R. 1988. Mitochondrial DNA polymor- phisms in five Old World subspecies of honey bee and in New World hybrids, pp. 303-312. In G. R Needham et al. [eds.], Africanized honey bees and bee mites. Horwood, Chichester, England

Smith, D. R. \& W. M. Brown. 1988. Polymorphism in mitochondrial DNA of European and Africanized honeybees (Apis mellifera). Experientia 44: 257-260

Solignac, M., M. Monnerot \& J.-C. Mounolou. 1986. Concerted evolution of sequence repeats in Drosoph ila mitochondria DNA. J. Mol. Evol. 24: 53-60.

Spivak, M., T. Ranker, O. R. Taylor, W. Taylor \& L. Davis. 1988. Discrimination of Africanized hones bees using behavior, cell size, morphometrics, and a newly discovered isozyme polymorphism, pp. 313 324. In G. R. Needham et al. [eds.], Africanized hone bees and bee mites. Horwood, Chichester, England

Sylvester, H. A. 1982 . Electrophoretic identification of Africanized honey bees. J. Apic. Res. 21: 93-97.

Tegelström, H. 1987. Transfer of mitochondrial DNA from the northern red-backed vole (Cleithrionomy rutilus) to the bank vole (C. glareolus). J. Mol. Evol 24: 218-227.

Vlasak, I., S. Burgschwaiger \& G. Kreil. 1987. Nucleotide sequence of the large ribosomal RNA of honeybee mitochondria. Nucleic Acids Res. 15: 2388.

Wright, J. W., C. Spolsky \& W. M. Brown. 1983. The origin of the parthenogenetic lizard Cnemidophorus laredoensis inferred from mitochondrial DNA anal. ysis. Herpetologica 39: 410-416.

Received for publication 25 July 1988; accepted 18 April 1989 